Z Badań nad Książką i Księgozbiorami Historycznymi 2019. T. specjalny: Dla Niepodległej The Studies into the History of the Book and Book Collections 2019. Special issue: For an Independent Poland

\title{
Biblioteki szkolne gimnazjów lwowskich w okresie międzywojennym
}

\section{Abstract \\ School libraries of lower secondary schools in Lviv during the interwar period}

School libraries in Lviv gymnasiums were treated as an important element of scientific collections and had important didactic functions - as a source of knowledge and a tool for educational influence. Separate libraries for teachers and students existed. The latter were sometimes divided by language (e.g. German, Ukrainian library) or specificity of collections (e.g. library of school textbooks, notes for choral singing). In addition to books, schools also subscribed to numerous magazines for teachers and junior high school students, which were made available in the reading rooms of some libraries. The Lviv gymnasiums acquired an impressive collection of scientific, popular and literature books. The state of student readership was very good.

Key words: education - libraries - secondary schools - Lviv.

Słowa kluczowe: edukacja - biblioteki - gimnazja - Lwów.

„Z Badań nad Książką i Księgozbiorami Historycznymi” - Udział zagranicznych recenzentów w ocenie publikacji; Stworzenie anglojęzycznej wersji wydawniczej publikacji; Digitalizacja tomów archiwalnych rocznika w celu zapewnienia otwartego dostępu do nich przez Internet oraz wdrożenie i utrzymanie cyfrowej platformy redakcyjnej - zadanie finansowane w ramach umowy nr 653/P-DUN/2019 ze środków Ministra Nauki i Szkolnictwa Wyższego przeznaczonych na działalność upowszechniającą naukę. 
Początki średniego szkolnictwa lwowskiego sięgają połowy XVIII w. Jednak zasadniczy kształt gimnazjów ustalony został w drugiej połowie XIX w., po Wiośnie Ludów i po wydaniu przez wiedeńskie władze oświatowe Zarysu organizacyjnego dla gimnazjów i szkót realnych ${ }^{1}$. Placówki te tworzyły zróżnicowany zbiór instytucji oświatowych, różniących się wielkością, poziomem nauczania czy typem własności. Najważniejszą grupę tworzyły szkoły państwowe, wyłącznie męskie, dopiero w na przełomie XIX i XX w. pojawiły się szkoły prywatne, głównie żeńskie (po dopuszczeniu kobiet do studiów wyższych w monarchii habsburskiej) ${ }^{2}$. Prawie wszystkie szkoły średnie Lwowa swoje początki wywodziły jeszcze z czasów autonomii galicyjskiej. W okres niepodległości weszły więc $\mathrm{z}$ własną tradycją oraz dorobkiem, zarówno intelektualnym jak i materialnym. Trudne były pierwsze lata powojenne, gdyż szkoły poniosły dość poważne straty w okresie I wojny światowej, a także podczas działań zbrojnych toczonych w 1919 i 1920 r. Na mozaikę oświatową miasta składało się przede wszystkim 14 gimnazjów państwowych (13 męskich i jedno żeńskie - im. Królowej Jadwigi, upaństwowione w 1920 r). Oprócz szkół polskich była też duża państwowa placówka ukraińska - dawne gimnazjum ,akademickie” (wraz z filią) oraz kilkanaście szkół prywatnych. Te ostatnie prowadzone były przez związki i stowarzyszenia, kongregacje religijne oraz osoby świeckie. Żydowskie Towarzystwo Szkoły Ludowej i Średniej (ŻTSLiŚr) było koncesjonariuszem prywatnych gimnazjów (humanistycznego i klasycznego) - męskiego i żeńskiego ${ }^{3}$. Prywatne gimnazjum żeńskie prowadziło Towarzystwo „Ridna Szkoła” Ukraińskiego Towarzystwa Pedagogicznego ${ }^{4}$. Natomiast posiadaczem prywatnego gimnazjum żeńskiego im. J. Słowackiego było Towarzystwo Prywatnego Gimnazjum im. J. Słowackiego, a w 1933 r. po zmianie właściciela Polskie Stowarzyszenie Kobiet z Wyższym Wykształceniem 5 . Wśród szkół o charakterze wyznaniowym trzy gimnazja

1 Entwurf der Organisation der Gymnasien und Realschulen in Österreich, Wien 1849.

2 B. Czajecka, «Z domu w szeroki świat». Droga kobiet do niezależności w zaborze austriackim w latach 1890-1914, Kraków 1990; A. Bilewicz, Prywatne średnie, ogólnoksztatcace szkolnictwo żeńskie w Galicji w latach 1867-1914, Wrocław 1997; M. Stinia, Gimnazjum klasyczne czy realne? Dylematy średniego szkolnictwa prywatnego w Galicji 1867-1914, [w:] Galicja. Studia z dziejów społeczno-gospodarczych, red. M. Baczkowski, T. Kargol, Kraków 2017, s. 53-66.

3 Archiwum Wojewódzkie we Lwowie (AWL), fond 1262, opis 201, sprawa 1-5, Prywatne męskie gimnazjum klasyczne Żydowskiego Towarzystwa Szkoły Ludowej i Średniej we Lwowie.

4 Od 1934 r. szkołę prowadziła fundacja „Ridnej Szkoły” im. Eliasza i Janiny Kokorudzów. Centralne Państwowe Archiwum Historyczne Ukrainy we Lwowie. Zespół Kuratorium Okręgu Szkolnego Lwowskiego (CDIAUL), fond 179, opis 3, sprawa 846, k. 44-55. Szerzej zob. Privatna divoča gimnaziâ «Rìdnoï školi» Ukraïns'kogo pedagogičnogo tovaristva imenì İlli ta İvanni Kokorudzìv u L'vovì, Drogobič 1997.

5 AWL, fond 1262, opis 200, sprawa 3, Sprawozdanie z wizytacji prywatnego gimnazjum żeńskiego im. J. Słowackiego przeprowadzone przez inspektora Romana Koestlicha w roku 1931; AWL, fond 1262, opis 200, sprawa 7, Sprawozdanie z wizytacji prywatnego gimnazjum żeńskiego 
utrzymywane były przez Ewangelicką Gminę Wyznaniową (koedukacyjne, męskie oraz żeńskie z niemieckim językiem wykładowym) ${ }^{6}$, funkcjonowały też greckokatolickie żeńskie gimnazjum ss. bazylianek z ukraińskim językiem nauczania ${ }^{7}$ oraz szkoły żeńskie, rzymskokatolickie prowadzone przez zgromadzenia ss. de Notre Dame, ss. Najświętszej Rodziny z Nazaretu, ss. sercanek oraz ss. urszulanek ${ }^{8}$. Od roku szkolnego 1933/1934 zorganizowano ponadto gimnazjum żeńskie pp. benedyktynek łacińskich ${ }^{9}$, a tuż przed wojną (od roku szkolnego 1937/1938) rozpoczęło działalność prywatne gimnazjum męskie Towarzystwa Salezjańskiego ${ }^{10}$. Siedem szkół średnich było własnością osób prywatnych: Gimnazjum Żeńskie im. Narcyzy Żmichowskiej (właściciel Maria Frenklówna), Prywatne Gimnazjum Realne im. H. Jordana (własność Mieczysława Kistryna), Prywatne Gimnazjum Żeńskie im. A. Mickiewicza (właściciel Olga Filippi-Żychowiczowa), Prywatne Gimnazjum Żeńskie dr Adeli Karp-Fuchsowej, Prywatne Gimnazjum Żeńskie (własność Józefy S. Goldblatt-Kamerling), Zakłady Naukowo-Wychowawcze, a w nich Prywatne Gimnazjum Żeńskie (właściciel Zofia Strzałkowska, następnie własność fundacji jej imienia i spadkobierców) ${ }^{11}$ oraz gimnazjum żeńskie będące własnością Cyprjanny Brückówny ${ }^{12}$.

im. Juliusza Słowackiego przeprowadzone przez inspektora Zygmunta Gerstmana w 1932, 1933, 1934, 1935, 1936, 1937, 1938 r.; CDIAUL, fond 179, opis 3, sprawa 894, Korespondencja w sprawie przejęcia gimnazjum Słowackiego przez Stowarzyszenie Kobiet z Wyższym Wykształceniem (1933-1935), k. 1-29.

6 AWL, fond 1262, opis 203, sprawa 1-31, Prywatne koedukacyjne gimnazjum z j. niemieckim Ewangelickiej Gminy Wyznaniowej we Lwowie. Szerzej zob. R. Romantsow, Polityka władz polskich wobec szkolnictwa żydowskiego we Lwowie w latach 1919-1939, Lublin 2015 (niepublikowana praca doktorska).

AWL, fond 1262, opis 202, sprawa 2, Sprawozdanie dyrektora szkoły SS. Bazylianek w roku szkolnym 1937/1938.

8 AWL, fond 1262, opis 204, sprawa 1, Sprawozdanie dyrekcji gimnazjum SS Urszulanek za rok szkolny 1925/1926; tamże, fond 1262, opis 204, sprawa 4, Sprawozdanie dyrekcji gimnazjum SS Urszulanek za rok szkolny 1932/1933; tamże, fond 1262, opis 204, sprawa 6, Sprawozdanie dyrekcji gimnazjum SS Urszulanek za rok szkolny 1934/1935; tamże, fond 1262, opis 204, sprawa 8, Sprawozdanie dyrekcji gimnazjum SS Urszulanek za rok szkolny 1936/1937.

9 CDIAUL, fond 179, opis 3, sprawa 860, Sprawozdania klasowych kierowników w gimnazjum PP Benedyktynek Łacińskich o stanie nauczania i zajęciach pozalekcyjnych 1934-1935, k. 1-75.

10 Tamże, fond 179 , opis 3, sprawa 873, Pisma dotyczące prywatnego gimnazjum męskiego Towarzystwa Salezjańskiego (1938), k. 1-4.

11 W 1938 r. po długich pertraktacjach pomiędzy władzami a spadkobiercami Z. Strzałkowskiej i nieudanej próbie upaństwowienia, szkoła została ostatecznie przejęta przez Towarzystwo Szkoły Ludowej, zob. CDIAUL, fond 179, opis 3, sprawa 883, Sprawa sprzedaży na własność państwową gimn. Strzałkowskiej (1934-1939).

12 Spis nauczycieli szkót wyższych, średnich, zawodowych, seminariów nauczycielskich oraz wykaz zakładów naukowych $i$ władz szkolnych, zestawił Z. Zagórowski, Warszawa-Lwów 1926, R. 2, s. $144-145$. 
Szkoły lwowskie należały z reguły do instytucji średniej wielkości, do których uczęszczało około 200-300 uczniów ${ }^{13}$. Zdarzały się jednak placówki dużo większe - w gimnazjum żeńskim im. Królowej Jadwigi w roku szkolnym 1920/1921 naukę rozpoczęło 611 i ukończyło 589 uczennic $^{14}$, w gimnazjum ukraińskim uczyło się około tysiąca (łącznie w zakładzie głównym i filii) ${ }^{15}$, a w V gimnazjum im. S. Żółkiewskiego - 690 rozpoczęło i 648 ukończyło $(1928 / 1929)^{16}$. W okresie dwudziestolecia międzywojennego nie uległ zasadniczym zmianom stan lokalowy szkół. Wybudowano wprawdzie kilka nowoczesnych obiektów oświatowych, jednak potrzeby były znacznie większe. W związku ze zróżnicowanym składem etnicznym miasta wśród gimnazjów prywatnych znajdowały się szkoły adresujące swoją ofertę do uczniów polskich, ukraińskich, żydowskich i niemieckich. Do większości szkół uczęszczali uczniowie różnych narodowości i wyznań.

To duże zróżnicowanie wielkościowe, własnościowe i jakościowe szkół średnich Lwowa miało istotny wpływ na rozmaitość stanu szkolnych bibliotek, wielkość zasobów, form i sposobów przechowywania oraz katalogowania zbiorów, a przede wszystkim na kształt edukacji czytelniczej.

Z punktu widzenia realizacji celów edukacyjnych i wychowawczych istnienie biblioteki szkolnej było warunkiem sine qua non ${ }^{17}$. Budowę księgozbioru

13 Naczelnik Wydziału Szkół Średnich w Kuratorium Okręgu Szkolnego Lwowskiego Mieczysław Ziemnowicz oceniał, że 200 uczniów to liczba wystarczająca do osiągnięcia samowystarczalności szkoły, zob. CDIAUL, fond 179, opis 3, sprawa 883, Sprawa sprzedaży na własność państwową gimn. Strzałkowskiej (1934-1939), k. 101.

14 Sprawozdanie dyrekcji państwowego gimnazjum realnego żeńskiego imieniem Królowej Jadwigi we Lwowie, za rok szkolny 1920/1921, Lwów 1921, s. 8.

15 Zvit direkciï akademičnoï gimnazï u L'vovì za škil'nij rìk 1920-1921, L'vìv 1921, s. 14; Zvidomlennâ pro žitti gimnazï̈ z ukraïis'kô movồ navčanniâ-filj u L'vovì v 1937-1938 škil'nomu rocì, Lv'ìv 1938, s. 87.

16 Sprawozdanie dyrekcji państwowego gimnazjum V im. Hetmana Stanisława Żótkiewskiego we Lwowie za rok szkolny 1928/1929, Lwów 1929, s. 23.

17 Zagadnienie bibliotek szkolnych posiada już dość pokaźną literaturę. Zarówno pod względem prac o charakterze ogólnym (H. Falkowska, $Z$ dziejów polskich bibliotek szkolnych, Warszawa 1966; M. Olczak-Kardas, Biblioteki uczniowskie szkół powszechnych w Polsce w latach 1918-1939, „Studia Bibliologiczne Akademii Świętokrzyskiej” 2005, t. 9, s. 181-194; J. Szocki, Biblioteki szkolne w II Rzeczypospolitej, „Chowanna” 1988, t. 32, z. 4, s. 447-463), jak i opracowań szczegółowych, dotyczących poszczególnych typów szkół lub konkretnych placówek oświatowych (I. Kaczmarek, Biblioteki szkolne $w$ Lodzi $w$ dwudziestoleciu międzywojennym. Przegląd działalności, „Acta Universitatis Lodziensis. Folia Librorum” 2015, nr 1, s. 33-57; H. Langer, Ksiegozbiory uczniów i nauczycieli w Państwowym Gimnazjum Polskim im. Antoniego Osuchowskiego w Cieszynie w okresie międzywojennym, [w:] Zagadnienia wydawnicze - dzieje ksiązki, prasy i bibliotek, red. A. Sitkowa, Katowice 2011, Studia Bibliologiczne, t. 19, s. 63-87). Na temat lwowskich bibliotek gimnazjalnych istnieje syntetyczny artykuł Marty Nadrahy, w którym autorka skupiła się na charakterystyce ilościowej księgozbiorów. Ponadto w znacznej części, mimo tytułu, tekst dotyczy szkolnictwa powszechnego, zob. M. Nadraga, Škil'nì (gimnazìni) biblioteki mižvoênnogo L'vova. Organizacìjni zasadi formuvannâ ì kil 'kicnij sklad fondiv, „Vìsnik L'vìvs'kogo Universitetu. Serìa Knigoznavstvo, Bỉblìotekoznavstvo ta İnformacijnì Tehnoloiì” 2014, t. 9, s. 74-80. 
rozpoczynano wraz z założeniem szkoły, a więc w związku z różnym czasem tworzenia szkół istniały też znaczące różnice w strukturze wewnętrznej i organizacji pracy poszczególnych bibliotek. W 20-leciu międzywojennym zachowano zasadniczy zrąb rozwiązań wypracowanych w okresie autonomicznym, jednak młode państwo polskie szybko zaproponowało własne rozwiązania prawne. Już w 1919 r. wydano okólnik nakazujący porządkowanie zbiorów i nadsyłanie do władz zwierzchnich sprawozdań o stanie bibliotek szkolnych $^{18}$. Nieco później uporządkowano kwestie wynagrodzeń ${ }^{19}$. Zgodnie z ustawą z 1923 r. za opiekowanie się zbiorami biblioteki uczniowskiej można było zaliczyć pedagogowi dwie godziny lekcyjne tygodniowo, natomiast prowadzenie biblioteki nauczycielskiej nie było dodatkowo płatne.

Fot. 1. Exlibris Biblioteki I Państwowego Gimnazjum im. Mikołaja Kopernika we Lwowie. Źródło: Rudolf Mękicki, Portret Mikołaja Kopernika na ekslibrisie Biblioteki Państwowego Gimnazjum im. Kopernika we Lwowie, 193, [online] 5http://www.kpbc.ukw.edu.pl/dlibra/doccontent?id=44402 [dostęp 21.10. 2019]

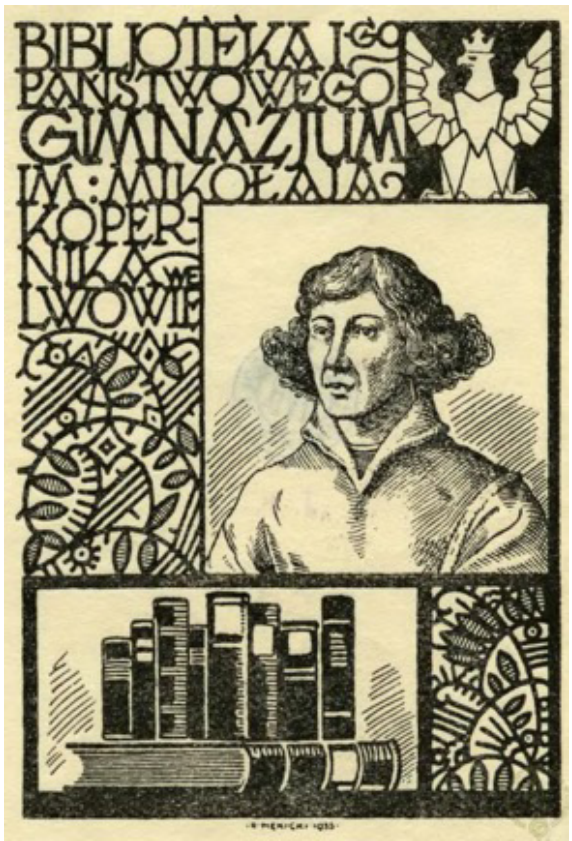

18 Okólnik No 8950/19 S II do Dyrekcji wszystkich państwowych szkół średnich w sprawie uporządkowania księgozbiorów, Dz. Urz. MWRiOP 1919, nr 9, poz. 28.

19 Ustawa z dnia 9 października 1923 r. o uposażeniu funkcjonariuszy państwowych i wojska, Dz. U. R. P. 1923, nr 116, poz. 924; Okólnik Ministra Wyznań Religijnych i Oświecenia Publicznego do Kuratoriów Okręgów Szkolnych w sprawie wykonania rozdziału 4 działu F ustawy z dnia 9 października 1923 r. o uposażeniu funkcjonariuszy państwowych i wojska, Dz. Urz. MWRiOP 1924, nr 8, poz. 74 . 
Wszystkie szkolne księgozbiory podzielone były na mniejsze jednostki. Stosowano tu różne koncepcje organizacyjne, jednak główny podział polegał na wyodrębnieniu tak zwanych bibliotek nauczycielskich i bibliotek uczniowskich, zachowywano w ten sposób tradycję z epoki autonomicznej. Wiele szkół posiadało bogate zbiory literatury naukowej i dydaktycznej, starano się nadążać za „nowościami” w nauce i metodyce, choć zwłaszcza po reformie z 1932 r. zauważano niekiedy braki w tym zakresie. Wbrew nazwie z biblioteki tej mogli korzystać również uczniowie ${ }^{20}$. W zakładach posiadających jeszcze XIX-wieczne początki liczba książek wynosiła po kilka tysięcy. Największe zbiory posiadały gimnazja II, III, IV, V i gimnazjum ukraińskie (tab. 1).

Tab. 1. Liczba książek w bibliotekach nauczycielskich w wybranych państwowych gimnazjach Lwowa w okresie międzywojennym

\begin{tabular}{|c|c|c|}
\hline Gimnazjum & Rok szkolny21 & Liczba dzieł \\
\hline II im. K. Szajnochy & $1928 / 1929$ & 7081 \\
\hline III im. Króla Stefana Batorego & $1929 / 1930$ & $5200(7072)^{*}$ \\
\hline IV im. J. Długosza & $1928 / 1929$ & 3493 \\
\hline V im. S. Żółkiewskiego & $1928 / 1929$ & $1895(8533)$ \\
\hline
\end{tabular}

* W nawiasach liczba tomów.

Źródło: Sprawozdanie dyrekcji państwowego gimnazjum II im. Karola Szajnochy za rok szkolny 1928/1929, Lwów 1929, s. 6; Sprawozdanie dyrekcji państwowego gimnazjum im. Króla Stefana Batorego za rok szkolny 1928/1929, Lwów 1929, s. 14-15; Sprawozdanie dyrekcji państwowego gimnazjum im. Jana Dlugosza za rok szkolny 1928/1929, Lwów 1929, s. 17; Sprawozdanie dyrekcji państwowego gimnazjum V im. Hetmana Stanistawa Żótkiewskiego we Lwowie za rok szkolny 1928/1929, Lwów 1929, s. 10.

Na początku okresu międzywojennego w szkołach państwowych usamodzielnionych po przekształceniu z filii w placówki odrębne (gimnazja: IX, X, XI i XII) biblioteki nauczycielskie liczyły z reguły około 300-500 woluminów (a niekiedy nawet mniej, jak w gimnazjum XII w roku szkolnym 1928/1929 gdzie było ich zaledwie $93^{22}$ ). Natomiast najsłabiej wyposażone były biblioteki tego typu w szkołach prywatnych. W sprawozdaniach $\mathrm{z}$ reguły podawana była ogólna liczba książek, bez podziału na rodzaje zbiorów, ale dla przykładu można podać, że w gimnazjum J. Goldblatt-Kamerling tuż przed wybuchem

20 Tak było w III gimnazjum, gdzie z biblioteki nauczycielskiej korzystali również uczniowie klas VII i VIII. Sprawozdanie dyrekcji państwowego gimnazjum im. Króla Stefana Batorego za rok szkolny 1927/1928 z uwzględnieniem dziesięciolecia 1918-1928, Lwów 1928, s. 25.

21 Pewna dowolność przy charakterystyce szkolnych zbiorów oraz brak danych uniemożliwia wykonanie zestawienia porównującego stan bibliotek w tym samym roku szkolnym. Na problem ten zwracała również uwagę M. Nadraga, zob. M. Nadraga, Škil 'nì (gìmnazijnì) biblioteki..., s. 78.

22 I. Sprawozdanie dyrekcji państwowego gimnazjum XII. im. Stanisława Szczepanowskiego we Lwowie za rok szkolny 1928/1929, Lwów 1929, s. 14. 
I wojny światowej (w roku szkolnym 1912/1913) biblioteka nauczycielska liczyła 83 dzieła (w 191 tomach) ${ }^{23}$. Nieco lepiej wyglądał stan ilościowy w gimnazjum Z. Strzałkowskiej, gdzie księgozbiór naukowy podzielony był na dwa działy. Pierwszy obejmował pedagogikę, historię wychowania, dydaktykę, pedeutologię (wówczas nazywaną pedologią) oraz pokrewne i liczył łącznie 315 tomów. Drugi obejmował filozofię, psychologię, etykę i estetykę - 70 dzieł w 98 tomach $^{24}$.

Z reguły najwięcej książek liczyły biblioteki uczniowskie. Ich zasoby i organizacja w poszczególnych szkołach były bardzo odmienne. Dotyczyło to podziałów wewnętrznych, tworzenia bibliotek „specjalnych”, a także miejsca przechowywania i zasad wypożyczania. W niektórych szkołach wraz z rozrostem zasobów bibliotecznych dokonywano podziałów, przekazując książki do poszczególnych gabinetów przedmiotowych, do uczniowskich kółek zainteresowań, czytelni, harcerstwa, a nawet tworzono biblioteki klasowe. Niekiedy zbiory były dzielone na książki przeznaczone dla uczniów gimnazjum niższego (kl. I-IV) i wyższego (kl. V-VIII). Po wprowadzeniu reformy jędrzejewiczowskiej i pojawieniu się dwuletniego liceum wydzielano również biblioteki dla tego typu szkoły. Praktycznie zawsze stosowany był podział pod względem językowym. Funkcjonowały więc biblioteki: polska, niemiecka, ruska (ukraińska), judaistyczna czy francuska. Książki w języku niemieckim nie były jedynie „spadkiem” po epoce autonomicznej - księgozbiory były aktualizowane i uzupełniane i liczyły niekiedy po kilkaset egzemplarzy. W 20-leciu największe zasoby książek napisanych po niemiecku (oprócz II gimnazjum, w którym do 1920 r. język ten był również językiem wykładowym) posiadały: V gimnazjum - 916 dzieł (1931/1932), IV gimnazjum - 520 (1925/1926), VII gimnazjum - 444 (1934/1935). Wydzielano też zbiory przedmiotowe, takie jak biblioteka podręczna katechety, kultury klasycznej, geograficzna, biologiczna, fizyczna itp. W XII gimnazjum im. Stanisława Szczepanowskiego na początku lat 30. założono osobne biblioteki podręczne: przyrodniczą, robót ręcznych i rysunków oraz fizykochemiczną ${ }^{25}$. Z bardziej interesujących kolekcji można wymienić wydzielony w bibliotece VIII gimnazjum zbiór nut do śpiewu chóralnego (w roku szkolnym 1926/1927 liczył 19 pozycji inwentarzowych) ${ }^{26}$. Z kolei męskie gimnazjum żydowskie posiadało (wspólne dla

${ }^{23}$ I. Sprawozdanie dyrekcji prywatnego żeńskiego gimnazjum z prawem publiczności Józefy S. Goldblatt-Kamerling we Lwowie za rok szkolny 1912/1913, Lwów 1913, s. 12.

${ }^{24}$ Zakłady Naukowe Żeńskie z prawem publiczności im. Zofii Strzatkowskiej we Lwowie. Sprawozdanie za rok 1926/1927, Lwów 1927, s. 43, 57.

25 Sprawozdanie dyrekcji państwowego gimnazjum XII. im. Stanisława Szczepanowskiego we Lwowie za rok szkolny 1931/1932, Lwów 1932, s. 9.

26 Sprawozdanie dyrekcji państwowego gimnazjum VIII. im. Króla Kazimierza Wielkiego we Lwowie za rok szkolny 1926/1927, Lwów 1927, s. 42. 
szkoły żeńskiej i męskiej) biblioteki beletrystyczne w języku polskim, hebrajskim i niemieckim, bibliotekę naukową o charakterze ogólnym oraz biblioteki naukowe specjalne (polonistyczną, judaistyczną, kultury klasycznej, geograficzną, biologiczną i fizyczną). Dyrekcja w swoim sprawozdaniu podkreślała, że jest to zbiór dostosowany do programów szkolnych i do zainteresowań uczniowskich ${ }^{27}$.

Niezmiernie ciekawym i popularnym pomysłem było gromadzenie książek szkolnych w tzw. bibliotece podręczników szkolnych. Jak stwierdzono w księdze pamiątkowej IV gimnazjum: „Są one - wobec drożyzny książek szkolnych - prawdziwym dobrodziejstwem nie tylko dla młodzieży ubogiej"28. Czasem zbiory te osiągały znaczące rozmiary - w tymże IV gimnazjum były to 4372 woluminy (1925/1926); w gimnazjum ukraińskim 1793 (1931/1932). W III gimnazjum im. Stefana Batorego w jej tworzenie (i wieloletnią opiekę nad zbiorami) zaangażował się Marian Golias - nauczyciel tej szkoły, znany filolog klasyczny, autor podręczników do nauki języka greckiego i łacińskiego oraz wydawca tekstów antycznych ${ }^{29}$.

W większości szkół istniały stosunkowo niewielkie biblioteki klasowe (,gmin klasowych”), których niewątpliwą zaletą był łatwy dostęp do zasobu i dopasowanie lektury do wieku uczniów. Jednak zdarzały się wypadki, gdy czyniono odwrotnie. Na przykład w Zakładach Naukowo-Wychowawczych im. Z. Strzałkowskiej w roku szkolnym 1926/1927 uznano system bibliotek klasowych za „niekorzystny i niepraktyczny”, dlatego urządzono wspólną wypożyczalnię pod opieką jednego nauczyciela. Obejmowała ona trzy działy: książki z dziedziny przedmiotów pedagogicznych (206 tomów), podręczniki szkolne (290 tomów) i książki do czytania (940 tomów). Jako odrębną pozostawiono jednak bibliotekę „książek ruskich”, którą zaczęto wówczas tworzyć (liczyła 93 dzieła w 145 tomach). System ten zdał egzamin, gdyż jak obliczono, we wcześniejszym systemie organizacyjnym księgozbioru ta sama liczba uczennic w ciągu roku przeczytała 881 książek, a po stworzeniu „wypożyczalni wspólnej" aż 2645, czyli trzykrotnie więcej ${ }^{30}$.

Częstotliwość korzystania z bibliotek szkolnych była znaczna. Z przytaczanych przez dyrekcje szkół danych wynika, że średnio uczniowie wypożyczali

27 Sprawozdanie dyrekcji z organizacji pracy na rok szkolny 1935/1936, „Sprawozdawca. Pismo dla młodzieży Gimnazjum Męskiego ŻTSLiŚr. we Lwowie” 1935/1936, t. 7, z. 15, s. 7.

28 Księga pamiatkowa 50-lecia gimnazjum im. Jana Dlugosza we Lwowie, Lwów 1928, s. 47.

29 Sprawozdanie dyrekcji państwowego III. gimnazjum im. Króla Stefana Batorego we Lwowie za rok szkolny 1929/1930, Lwów 1930, s. 16. Szerzej zob. I. Kaczor, Znaczace postacie łódzkiej filologii klasycznej (Jan Oko, Jerzy Schnayder, Marian Golias, Stefan Oświecimski), „Collectanea Philologica" 2003, t. 7, s. 97-101.

30 Zakłady Naukowo-Wychowawcze Żeńskie im. Zofii Strzalkowskiej we Lwowie. Sprawozdanie za rok szkolny 1926/1927..., s. 43, 57-59. 
kilkanaście książek rocznie ${ }^{31}$. Duże znaczenie bibliotek szkolnych wynikało również z faktu, że w wielu domach uczniowie nie posiadali własnych księgozbiorów. $\mathrm{Z}$ ankiety przeprowadzonej $\mathrm{w}$ gimnazjum żydowskim $\mathrm{w}$ roku szkolnym 1935/1936 wynikało, że na 307 uczniów tylko 164, a więc niewiele więcej niż połowa posiadało własną bibliotekę domową̨ ${ }^{32}$. Wysoki poziom czytelnictwa związany był także z koniecznością przyswojenia lektur szkolnych. Na przykład w gimnazjum żydowskim uczniowie klas I i II mieli obowiązek przeczytać w ciągu roku dwadzieścia lektur uzupełniających naukę języka polskiego $^{33}$, a w klasie VIII obowiązkowa była lektura filozoficzna ${ }^{34}$.

Bardzo różne były lokalizacje szkolnych zbiorów książkowych. Zależało to od możliwości lokalowych często przepełnionych szkół, dlatego książki składowano z reguly w klasach lekcyjnych, a nawet na korytarzach (w zamykanych szafach). W III gimnazjum bibliotekę nauczycielską ulokowano w pokoju nauczycielskim (,sali posiedzeń”). Zbiory klasowe przechowywano najczęściej w poszczególnych gabinetach, co znacznie utrudniało dostęp do nich osobom $\mathrm{z}$ innych klas. Generalnie tylko w niewielu budynkach, zwłaszcza takich, które budowane były z przeznaczeniem na obiekty szkolne warunki gromadzenia i udostępniania książek można uznać za dobre. Tak było na przykład w Zakładach Naukowych Z. Strzałkowskiej, w gimnazjum ss. bazylianek ${ }^{35}$, czy VIII gimnazjum im. Kazimierza Wielkiego (po przeprowadzce w 1935 r. do nowego budynku).

Bardzo duże zróżnicowanie było widoczne także jeśli chodzi o stan zasobów. Z reguły więcej książek liczyła biblioteka uczniowska, lecz czasem, zwłaszcza w gimnazjach z długą tradycją, bywało odwrotnie. I tak w III gimnazjum im. Stefana Batorego w roku szkolnym 1929/1930 - biblioteka nauczycielska liczyła 5200 pozycji (7072 tomy) a uczniowska tylko 1072; w IV gimnazjum im. J. Długosza w 1929/1930 - biblioteka nauczycielska zawierała 3493 woluminy a uczniowska 1832 (polska 1312, niemiecka 520) ${ }^{36}$. Natomiast

31 Przykładowo średnia uczniowskich wypożyczeń w państwowym III gimnazjum na przełomie lat 20. i 30. wyniosła 20,4 książki (Sprawozdanie dyrekcji państwowego III. gimnazjum im. Króla Stefana Batorego we Lwowie za rok szkolny 1929/1930..., s. 15), a w prywatnych Zakładach Naukowo-Wychowawczych im. Z. Strzałkowskiej w połowie lat 20. - 10 książek (Sprawozdanie Zakładów Naukowo-Wychowawczych Żeńskich im. Zofii Strzałkowskiej we Lwowie za rok szkolny 1926/1927, Lwów 1927, s. 58).

32 Sprawozdanie dyrekcji z organizacji pracy na rok szkolny 1935/1936..., s. 7.

33 Tamże.

34 Sprawozdanie dyrekcji zaktadu za czas od 20 sierpnia 1934 do 22 grudnia 1934, „Sprawozdawca. Pismo dla młodzieży Gimnazjum Męskiego ŻTSLiŚr. we Lwowie” 1934/1935, t. 6, z. 14, s. 7.

35 AWL fond 1262, opis 202, sprawa 2, Sprawozdanie dyrekcji gimnazjum SS. Bazylianek w roku szkolnym 1937/38.

36 Szerzej na temat zasobu państwowych męskich gimnazjów zob. M. Nadraga, Škil'nì (gìmnazijni) biblioteki..., s. 70 (tab.). 
w VIII gimnazjum w połowie lat 20. biblioteka uczniowska była dwukrotnie większa od nauczycielskiej (998 wobec 505) ${ }^{37}$. Skromniejsze zasoby finansowe i późniejszy start szkół prywatnych powodowały, że ich księgozbiory rzadko przekraczały kilkaset egzemplarzy. Do wyjątków można zaliczyć gimnazjum Z. Strzałkowskiej, w którym biblioteka uczniowska liczyła 1896 dzieł $(1926 / 1927)^{38}$, gimnazjum Karola Petelenza im. A. Mickiewicza - 1553 $(1917 / 1918)^{39}$, czy gimnazjum żydowskie męskie ŻTSLiŚr - około 4000 tomów (1935/1936).

Trudności związane z budową młodego, niepodległego państwa i kryzysy gospodarcze odbijały się na tempie wzrostu zasobów bibliotecznych, które uzależnione było od zmieniających się możliwości finansowych szkół oraz ofiarności darczyńców. Nie bez znaczenia była także konieczność przeprowadzania weryfikacji i aktualizacji zbiorów. Ogólnie jednak należy uznać ponoszony wysiłek za duży - wynikało to także z faktu, że podczas corocznych wizytacji szkół wskazywano na konieczność powiększania księgozbiorów, co zalecano zwłaszcza szkołom prywatnym. Dla porównania stan szkolnej biblioteki X gimnazjum im. Henryka Sienkiewicza na początku lat 20. (1921/1922) wynosił 590 dzieł w bibliotece nauczycielskiej oraz $1076 \mathrm{w}$ uczniowskiej, a po 15 latach - odpowiednio - 2028 i 1570. Zwraca uwagę przede wszystkim blisko czterokrotny wzrost zasobu prac naukowych i dydaktycznych ${ }^{40}$.

Zakupy książek do bibliotek szkolnych finansowane były z różnych źródeł. Najczęściej była to subwencja dyrekcji. Uzyskiwano też pewne kwoty od Ministerstwa Wyznań Religijnych i Oświecenia Publicznego (przykładowo 29 VI 1929 r. przyznało ono $1700 \mathrm{zł}$ z funduszu na biblioteki uczniowskie dla III gimnazjum im. Stefana Batorego). Zdarzały się też darowizny indywidualne. Temu samemu gimnazjum rodzina śp. Franciszka Majchrowicza, byłego dyrektora szkoły, darowała w 1929 r. 232 dzieła, które razem z wcześniejszymi darowiznami umieszczono w osobnym dziale w bibliotece ${ }^{41}$. Działająca w V gimnazjum fundacja imienia byłego dyrektora szkoły Józefa Nogaja w roku szkolnym 1937/1938 przekazała 269 dzieła do biblioteki ${ }^{42}$. Książki

\footnotetext{
37 Sprawozdanie dyrekcji państwowego VIII gimnazjum im. Króla Kazimierza Wielkiego za rok szkolny 1926/1927, Lwów 1927, s. 12.

38 Sprawozdanie Zakładów Naukowo-Wychowawczych Żeńskich im. Zofii Strzatkowskiej we Lwowie za rok szkolny 1926/1927..., s. 43.

39 Ósme sprawozdanie dyrekcji Wyższego I Realnego Gimnazjum im. A. Mickiewicza we Lwowie za rok szkolny 1917/1918, Lwów 1918, s. 6.

40 Sprawozdanie dyrekcji gimnazjum $(X)$ im. Henryka Sienkiewicza we Lwowie za rok szkolny 1921/1922, Lwów 1922, s. 6; CDIAUL, fond 179, opis 3, sprawa 389, Sprawozdanie dyrekcji X gimnazjum im. Henryka Sienkiewicza we Lwowie za rok szkolny 1936/1937, k. 46-47.

41 Sprawozdanie dyrekcji państwowego III. gimnazjum im. Króla Stefana Batorego we Lwowie za rok szkolny 1929/1930..., s. 15.

42 CDIAUL fond 179, opis 3, sprawa 421, Sprawozdania z wizytacji V państwowego gimna-
} 
kupowano też z pieniędzy wypracowanych przez uczniów, na przykład ze składek członkowskich Czytelni uczniowskiej, zysków ze sklepików, kramików, dochodów z wypożyczania przyborów do gier i zabaw, sportu saneczkowego i narciarskiego. W VIII gimnazjum zaciągnięto nawet pożyczkę w szkolnej Lidze Obrony Powietrznej i Przeciwgazowej ${ }^{43}$.

Intensywnie wykorzystywany księgozbiór wymagał odpowiedniej opieki. Dlatego część pozyskiwanych kwot przeznaczano na oprawianie książek (przepisy zobowiązywały do obłożenia i zinwentaryzowania całego majątku). Opiekę nad książnicą, pełnił najczęściej nauczyciel przedmiotów humanistycznych (tzw. zawiadowca biblioteki). Angażowano też uczniów, zwłaszcza osoby będące w zarządzie Czytelni uczniowskiej. Wypożyczenia prowadzono na wybranych przerwach szkolnych lub w wyznaczonych godzinach popołudniowych. Najczęściej możliwe to było dwa razy w tygodniu (choć zdarzały się też szkoły udostępniające księgozbiór rzadziej lub częściej - od jednego do czterech razy w tygodniu).

Jednym z ważkich elementów polityki oświatowej było zwrócenie uwagi na dobór książek przeznaczonych dla szkolnych bibliotek ${ }^{44}$. W tym celu w 1923 r. powołano przy Ministerstwie Wyznań Religijnych i Oświecenia Publicznego 25-osobową Komisję Oceny Książek do Czytania dla Młodzieży Szkolnej ${ }^{45}$, złożoną z wybitnych naukowców, pedagogów i działaczy oświatowych. Książki dla bibliotek szkolnych kwalifikowała ona do trzech kategorii („konieczna”, „pożądana” bądź „dozwolona”), biorąc pod uwagę ich wartości wychowawcze, walory literackie i naukowe oraz aspekty formalne (poprawność stylu i języka, poprawność przekładu, wygląd zewnętrzny książki i jej trwałość). Uwzględniając możliwości percepcyjne młodego czytelnika, adresowano je do poszczególnych grup wiekowych (piątą, najwyższą grupę stanowiła młodzież - 15-18 lat). Opinie Komisji drukowano w latach 1924-1928 w „Bibliografii Pedagogicznej”, a orzeczenia o książkach zakwalifikowanych do użytku szkolnego zamieszczano systematycznie w „Dzienniku Urzędowym Ministerstwa Wyznań Religijnych i Oświecenia Publicznego”. W 1929 r.

\footnotetext{
zjum im. S. Żółkiewskiego we Lwowie (1934-1935), k. 2-3.

43 Sprawozdanie dyrekcji państwowego gimnazjum VIII. im. Króla Kazimierza Wielkiego we Lwowie za rok szkolny 1926/1927..., s. 44.

44 Szerzej K. Sanojca, Rola lwowskiego Państwowego Wydawnictwa Ksiażek Szkolnych w realizacji polityki oświatowej Drugiej Rzeczypospolitej, [w:] Kraków - Lwów. Książki, czasopisma, biblioteki. T. 8, red. H. Kosętka, Kraków 2006, Prace Monograficzne. Akademia Pedagogiczna im. Komisji Edukacji Narodowej w Krakowie, nr 455, s. 102-110; tenże, Relacje polsko-ukraińskie w szkolnictwie państwowym poludniowo-wschodnich województw Drugiej Rzeczypospolitej, Kraków 2013, Studia z Historii XX Wieku, t. 17, s. 278-293.

45 Rozporządzenie z 28 XI 1923 r. w sprawie utworzenia Komisji do oceny książek do czytania dla młodzieży szkolnej, Dz. Urz. MWRiOP 1924, nr 21, s. 187.
} 
wydano zbiorczy spis książek poleconych przez Komisję do bibliotek szkolnych $^{46}$. W tym samym roku dokonano reorganizacji zespołu, zmniejszając jego skład do siedmiu osób, uproszczono też kategoryzowanie książek dla bibliotek szkolnych, wprowadzając tylko dwie kategorie - „dozwolone” i ,niedozwolone" ${ }^{47}$. Ostateczne uporządkowanie trybu certyfikowania podręczników i innych pomocy szkolnych przyniosło rozporządzenie ministra WRiOP z 14 I 1937 r. O ocenie i używaniu książek, czasopism i pomocy szkolnych dla szkót powszechnych, szkót średnich ogólnokształcących i zakładów kształcenia nauczycieli ${ }^{48}$. Uwzględniało ono pięć rodzajów wydawnictw: podręczniki szkolne, książki pomocnicze dla uczniów, książki popularnonaukowe do bibliotek uczniowskich, książki z zakresu literatury pięknej do bibliotek uczniowskich oraz czasopisma dla młodzieży. Przewidywano też tworzenie komisji doraźnych. I taką była istniejąca od lat 20. przy Kuratorium Okręgu Szkolnego Lwowskiego Podkomisja Oceny Książek dla Szkół z Ruskim Językiem Nauczania. Funkcje tego gremium wykraczały poza recenzowanie książek - wyraźnie widoczny był jego udział w kreowaniu polityki wydawniczej, a w konsekwencji znaczny wpływ wywierany na kształt całej polityki oświatowej wobec Ukraińców. Procedura oceny książki przewidywała przygotowanie dwóch niezależnych opinii, formułowano wniosek kwalifikacyjny, odbywała się dyskusja, a następnie, po głosowaniu, wnioskowano o zaliczenie książki do odpowiedniej kategorii. Komisja zbierała się przeciętnie cztery do sześciu razy w roku, poddając ocenie jednorazowo od kilku do kilkunastu pomocy do różnych przedmiotów oraz książek przeznaczonych do bibliotek szkolnych. Następnie odpowiednie wykazy trafiały do MWRiOP, które podejmowało ostateczną decyzję. Jednym z celów, jaki postawiła sobie kuratoryjna podkomisja był przegląd i krytyczna ocena wydawnictw zakwalifikowanych do bibliotek uczniowskich i znajdujących się w wykazie ogłoszonym w „Dzienniku Urzędowym” Kuratorium Okręgu Szkolnego Lwowskiego w $1935 \mathrm{r}^{49}$ Zakres prac obejmował uzupełnienie zestawienia, podjęcie decyzji o ponownej weryfikacji niektórych pozycji z listy, ocenę książek dotąd niezgłoszonych, które mimo to znajdują się w bibliotekach

\footnotetext{
46 Spis ksiazżek poleconych do bibliotek szkolnych przez Komisję Oceny Ksiażek do Czytania dla Młodzieży Szkolnej przy MWRiOP w latach 1923-1928, Warszawa 1929.

47 J.Z. Białek, Literatura dla dzieci i młodzieży w latach 1918-1939. Zarys monograficzny. Materiaty, Warszawa 1987, s. 25.

48 Dz. Urz. MWRiOP 1937, nr 1, poz. 4.

49 Spis, liczący 362 pozycje, obejmował książki przeznaczone dla pięciu grup wiekowych: literatura dla przedszkoli, książki dla dzieci 7-8 letnich (czyli I i II klasy szkół powszechnych), książki dla III i IV klasy, książki dla klasy V i VI szkół powszechnych oraz dla I i II klasy szkół średnich, dla VII klasy szkół powszechnych oraz dla III i IV klasy szkół średnich nowego typu. Podzielono je również na pozycje sceniczne, pisane wierszem, popularnonaukowe, geograficzne, historyczne i podróżnicze (Książki, czasopisma. Wykaz książek dopuszczonych do bibliotek szkolnych z r. j. n., Dz. Urz. KOSLw 1935, nr. 12, s. 554-565).
} 
szkolnych, oraz opublikowanie nowej listy książek dopuszczonych do użytku szkolnego. Komitet rozpoczął pracę w marcu 1938 r., zwracając się do wszystkich wydawców o dostarczenie książek ukraińskich dla młodzieży szkolnej wydanych w latach 1936-1937 celem poddania ich ocenie. Wśród 275 nadesłanych publikacji dominowała literatura piękna - bajki, opowiadania, klasyka literatury ukraińskiej oraz tłumaczenia popularnych powieści przygodowych. W zestawie literatury popularnonaukowej najwięcej było pozycji poświęconych przyrodzie i geografii krajów pozaeuropejskich, natomiast skromny był wybór książek historycznych. Osobną grupę stanowiła literatura o charakterze metodycznym np. propozycje scenariuszy dla teatrów uczniowskich. W recenzjach bardzo wnikliwie analizowano zawartość i charakter pozycji literackich. Spora część książek była odrzucana z powodów wychowawczych, na przykład akcentowano brak walorów językowych, albo zbyt trudny, niedostosowany do poziomu uczniów tekst ${ }^{50}$. Niektóre pozycje odrzucano jako sprzeczne z zasadami wychowawczymi ${ }^{51}$. Oczywiście nie brakowało przypadków, gdy książek nie dopuszczano z powodu zawartych w nich elementów agitacji politycznej ${ }^{52}$.

Uwagę zwracał problem aktualizowania zbiorów. Dotyczyło to zwłaszcza tekstów niemieckojęzycznych. Na przykład w gimnazjum im. Żółkiewskiego wśród 176 książek w tym języku (za wyjątkiem dzieł klasyków) znaczna część była zdezaktualizowana i niedopasowana do obowiązujących programów nauczania $^{53}$. Po wprowadzeniu reformy jędrzejewiczowskiej na początku lat 30 . niekiedy sygnalizowano, że zasoby biblioteczne nie nadążają za zmianami w organizacji nauczania (zarówno w zakresie opracowań o charakterze dydaktycznym, jak i książek przeznaczonych dla młodzieży). Jak już wspomniano, problem dotyczył także tych dzieł, co do których były zastrzeżenia natury politycznej.

W zasobach bibliotek szkolnych znajdowały się także czasopisma ${ }^{54}$. Każda ze szkół prenumerowała kilka - kilkanaście tytułów. Najczęściej były to: „Chowanna”, „Muzeum”, „Oświata i Wychowanie”, „Fizyka i Chemia w Szkole”, „Ziemia”, „Wychowanie Fizyczne”, „Praca Ręczna w Szkole”, „Wiedza o Polsce”, „Wielka Historia Powszechna”, „Sport”. Zdarzała się nawet literatura naukowa (dla XII gimnazjum w darze przekazywano roczniki „Sprawozdań Akademii Umiejętności” w Krakowie) ${ }^{55}$.

50 CDIAUL, fond 179, opis 5, sprawa 311, Recenzje nieznanego autora książek wydanych przez Towarzystwo „Proswita” we Lwowie (1931), k. 66.

51 CDIAUL, fond 179, opis 1, sprawa 264, Recenzje podręczników ukraińskich (1937-1938), k. 52-57.

52 K. Sanojca, Relacje polsko-ukraińskie w szkolnictwie państwowym..., s. 278-293.

53 CDIAUL, fond 179, opis 3, sprawa 407, Sprawozdania, protokoły, korespondencja dotycząca działalności V państwowego gimnazjum im. S. Żółkiewskiego we Lwowie (1927-1928), k. 50.

54 Szerzej K. Sanojca, Czasopisma młodzieży szkolnej międzywojennego Lwowa, [w:] KrakówLwów. Książki-czasopisma - biblioteki. T. 7, red. H. Kosętka, Kraków 2005, s. 457-462.

55 Sprawozdanie dyrekcji państwowego gimnazjum XII. im. Stanisława Szczepanowskiego we 
W bibliotekach szkolnych gimnazjów lwowskich w ciągu wielu dziesiątków lat zgromadzono imponujący zestaw produkcji księgarskiej o bardzo zróżnicowanym charakterze. Oprócz pozycji o charakterze naukowym i dydaktycznym najistotniejszą część stanowiły lektury dla dzieci i młodzieży. Dzięki prowadzonym systematycznie wypożyczeniom z całym tym dorobkiem mogli zapoznawać się nauczyciele i uczniowie. Dlatego biblioteki szkolne posiadały znaczący wpływ na rozwój intelektualny uczniów i były pomocą w pracy wychowawczej szkoły. Pełniły też funkcję informacyjną i rekreacyjną, a uczniowie nabywali w nich umiejętności korzystania z dóbr kultury. Etap istnienia i działalności lwowskich bibliotek gimnazjalnych w dotychczasowym kształcie niestety zakończył się w 1939 r. W przeciwieństwie do bibliotek o charakterze naukowym, które w znacznym stopniu przetrwały zawieruchę wojenną i powojenne zmiany, ten gromadzony przez wiele lat materialny dorobek został praktycznie w całości zniszczony.

\section{Bibliografia}

Archiwalia

Archiwum Wojewódzkie we Lwowie, fond 1262.

Centralne Państwowe Archiwum Historyczne Ukrainy we Lwowie. Zespół Kuratorium Okręgu Szkolnego Lwowskiego, fond 179.

Publikacje

Białek J.Z., Literatura dla dzieci i młodzieży w latach 1918-1939. Zarys monograficzny. Materiaty, Warszawa 1987.

Bilewicz A., Prywatne średnie, ogólnoksztatcace szkolnictwo żeńskie w Galicji w latach 1867-1914, Wrocław 1997.

Czajecka B., «Z domu w szeroki świat». Droga kobiet do niezależności w zaborze austriackim w latach 1890-1914, Kraków 1990.

Entwurf der Organisation der Gymnasien und Realschulen in Österreich, Wien 1849.

Falkowska H., Z dziejów polskich bibliotek szkolnych, Warszawa 1966.

Kaczmarek I., Biblioteki szkolne w Lodzi w dwudziestoleciu międzywojennym. Przegląd działalności, „Acta Universitatis Lodziensis. Folia Librorum” 2015, nr 1, s. 33-57.

Kaczor I., Znaczące postacie łódzkiej filologii klasycznej (Jan Oko, Jerzy Schnayder, Marian Golias, Stefan Oświecimski), „Collectanea Philologica” 2003, t. 7, s. 97-101.

Książki, czasopisma. Wykaz książek dopuszczonych do bibliotek szkolnych z r. j. n., Dz. Urz. KOSLw 1935, nr 12, s. 554-565.

Księga pamiątkowa 50-lecia gimnazjum im. Jana Dtugosza we Lwowie, Lwów 1928. 
Langer H., Księgozbiory uczniów i nauczycieli w Państwowym Gimnazjum Polskim im. Antoniego Osuchowskiego w Cieszynie w okresie międzywojennym, [w:] Zagadnienia wydawnicze - dzieje ksiązki, prasy i bibliotek, red. A. Sitkowa, Katowice 2011, Studia Bibliologiczne, t. 19, s. 63-87.

Nadraga M., Škil'nì (gìmnazìjni) biblioteki mižvoênnogo L'vova. Organizacìjnì zasadi formuvannâ ì kil 'kìcnij sklad fondìv, „Vìsnik L'vìvs'kogo Universitetu. Serìâ Knigoznavstvo, Bìblìotekoznavstvo ta İnformacìjnì Tehnoloiī” 2014, t. 9, s. 74-80.

Okólnik Ministra Wyznań Religijnych i Oświecenia Publicznego do Kuratoriów Okręgów Szkolnych w sprawie wykonania rozdziału 4 działu F ustawy z dnia 9 października 1923 r. o uposażeniu funkcjonariuszy państwowych i wojska, Dz. Urz. MWRIOP 1924, nr 8, poz. 74 .

Okólnik No 8950/19 S II do Dyrekcji wszystkich państwowych szkół średnich w sprawie uporządkowania księgozbiorów, Dz. Urz. MWRIOP 1919, nr 9, poz. 28.

Olczak-Kardas M., Biblioteki uczniowskie szkół powszechnych w Polsce w latach 1918 1939, „Studia Bibliologiczne Akademii Świętokrzyskiej” 2005, t. 9, s. 181-194.

Ósme sprawozdanie dyrekcji Wyższego I Realnego Gimnazjum im. A. Mickiewicza we Lwowie za rok szkolny 1917/1918, Lwów 1918.

I. Sprawozdanie dyrekcji państwowego gimnazjum XII. im. Stanisława Szczepanowskiego we Lwowie za rok szkolny 1928/1929, Lwów 1929.

I. Sprawozdanie dyrekcji prywatnego żeńskiego gimnazjum z prawem publiczności Józefy S. Goldblatt-Kamerling we Lwowie za rok szkolny 1912/1913, Lwów 1913.

Privatna divoča gìmnaziâ «Ridnoï školi» Ukraïns'kogo pedagogičnogo tovaristva ìmeni Ìllì ta İvanni Kokorudzìv u L'vovì, Drogobič 1997.

Romantsow R., Polityka władz polskich wobec szkolnictwa żydowskiego we Lwowie w latach 1919-1939, Lublin 2015 (niepublikowana praca doktorska).

Rozporządzenie ministra WRiOP z 14 I 1937 r. o ocenie i używaniu książek, czasopism i pomocy szkolnych dla szkół powszechnych, szkół średnich ogólnokształcących i zakładów kształcenia nauczycieli, Dz. Urz. MWRiOP 1937, nr 1, poz. 4.

Rozporządzenie z 28 XI 1923 r. w sprawie utworzenia Komisji do oceny książek do czytania dla młodzieży szkolnej, Dz. Urz. MWRIOP 1924, nr 21.

Sanojca K., Czasopisma młodzieży szkolnej międzywojennego Lwowa, [w:] Kraków-Lwów. Książki-czasopisma-biblioteki. T. 7, red. H. Kosętka, Kraków 2005, s. 457-462.

Sanojca K., Relacje polsko-ukraińskie w szkolnictwie państwowym poludniowo-wschodnich województw Drugiej Rzeczypospolitej, Kraków 2013, Studia z Historii XX Wieku, t. 17.

Sanojca K., Rola lwowskiego Państwowego Wydawnictwa Książek Szkolnych w realizacji polityki oświatowej Drugiej Rzeczypospolitej, [w:] Kraków-Lwów. Książi, czasopisma, biblioteki. T. 8, red. H. Kosętka, Kraków 2006, Prace Monograficzne. Akademia Pedagogiczna im. Komisji Edukacji Narodowej w Krakowie, nr 455, s. 102-110.

Spis książek poleconych do bibliotek szkolnych przez Komisję Oceny Książek do Czytania dla Młodzieży Szkolnej przy MWRiOP w latach 1923-1928, Warszawa 1929. 
Spis nauczycieli szkół wyższych, średnich, zawodowych, seminariów nauczycielskich oraz wykaz zakładów naukowych $i$ władz szkolnych, zestawił Z. Zagórowski, WarszawaLwów 1926, R. 2.

Sprawozdanie dyrekcji gimnazjum (X) im. Henryka Sienkiewicza we Lwowie za rok szkolny 1921/1922, Lwów 1922.

Sprawozdanie dyrekcji państwowego gimnazjum im. Króla Stefana Batorego za rok szkolny 1927/1928 z uwzględnieniem dziesięciolecia 1918-1928, Lwów 1928.

Sprawozdanie dyrekcji państwowego gimnazjum realnego żeńskiego imieniem Królowej Jadwigi we Lwowie, za rok szkolny 1920/1921, Lwów 1921.

Sprawozdanie dyrekcji państwowego gimnazjum V im. Hetmana Stanisława Żółkiewskiego we Lwowie za rok szkolny 1928/1929, Lwów 1929.

Sprawozdanie dyrekcji państwowego gimnazjum VIII. im. Króla Kazimierza Wielkiego we Lwowie za rok szkolny 1926/1927, Lwów 1927.

Sprawozdanie dyrekcji państwowego gimnazjum XII. im. Stanisława Szczepanowskiego we Lwowie za rok szkolny 1930/1931, Lwów 1931.

Sprawozdanie dyrekcji państwowego gimnazjum XII. im. Stanisława Szczepanowskiego we Lwowie za rok szkolny 1931/1932, Lwów 1932.

Sprawozdanie dyrekcji państwowego III. gimnazjum im. Króla Stefana Batorego we Lwowie za rok szkolny 1929/1930, Lwów 1930.

Sprawozdanie dyrekcji z organizacji pracy na rok szkolny 1935/1936, „Sprawozdawca. Pismo dla młodzieży Gimnazjum Męskiego ŻTSLiŚr. we Lwowie” 1935/1936, t. 7, z. 15 , s. 6-14.

Sprawozdanie Zakładów Naukowo-Wychowawczych Żeńskich im. Zofii Strzałkowskiej we Lwowie za rok szkolny 1926/1927, Lwów 1927.

Sprawozdanie dyrekcji zakładu za czas od 20 sierpnia 1934 do 22 grudnia 1934, „Sprawozdawca. Pismo dla młodzieży Gimnazjum Męskiego ŻTSLiŚr. we Lwowie" 1934/1935, t. 6, z. 14, s. 3-11.

Stinia M., Gimnazjum klasyczne czy realne? Dylematy średniego szkolnictwa prywatnego w Galicji 1867-1914, [w:] Galicja. Studia z dziejów społeczno-gospodarczych, red. M. Baczkowski, T. Kargol, Kraków 2017, s. 53-66.

Szocki J., Biblioteki szkolne w II Rzeczypospolitej, „Chowanna” 1988, t. 32, z. 4, s. 447 463.

Ustawa z dnia 9 października 1923 r. o uposażeniu funkcjonariuszy państwowych i wojska, Dz. U. R. P. 1923, nr 116, poz. 924.

Zakłady Naukowe Żeńskie z prawem publiczności im. Zofii Strzałkowskiej. Sprawozdanie za rok 1926/1927, Lwów 1927.

Zvidomlennâ pro žitti gimnaziï z ukraïs 'kô̂ movô̂ navčanniâ-filj u L'vovì v 1937-1938 škil'nomu rocì, Lv'ìv 1938.

Zvit direkciï akademičnoï gimnazï u L'vovì za škil'nij rìk 1920-1921, L'vìv 1921. 